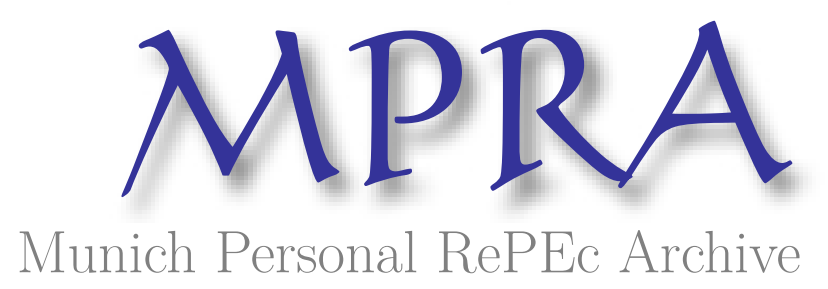

\title{
Dilemmas of public election
}

Estrada, Fernando

Universidad Externado de Colombia, Facultad de Finanzas, Gobierno y Relaciones Internacionales

April 2010

Online at https://mpra.ub.uni-muenchen.de/22289/

MPRA Paper No. 22289, posted 26 Apr 2010 06:07 UTC 


\title{
Dilemmas of public election
}

\author{
Fernando Estrada
}

\begin{abstract}
In this brief comment, the public choice theory ${ }^{1}$ aims to distinguish the dilemmas and conflicts in formal and empirical. The hypothesis argues that the reality more complex than the principles of choice of Pareto and Liberalism*. Both the ethics and politics are taking decisions that are not always in line with the requirements of rationality and complete information.
\end{abstract}

Keywords: Public choice theory, public election, rational choice, social welfare, economic psychology.

\section{Introduction}

Externalities need collective decisions to protect the identity of agents and their differences. It is a prerequisite, not only in the markets, but in open and democratic societies $^{2}$. However, these externalities are not met. Observe a public tender for contracts with the State in emerging countries, are transparent processes information and incentives for those who aspire to earn? It is not clear. Just as in the contracting state, a majority of collective choice processes fail in these conditions ${ }^{3}$. Presidential elections in Colombia, such as, can be decided by a simple majority vote, but the constitutional reforms introduced possibilities of coalitions between the first round losers. So they create conditions that allow for changes in voter preferences ${ }^{4}$.

In this sense, the policy also applies market allocation. In economic systems it is entirely impossible neutrality when making decisions that can affect everyone ${ }^{5}$. I like fruit for breakfast; you like eating bread with jam, a change in our preferences can offer

\footnotetext{
${ }^{1}$ Amartya K. Sen, Collective Choice and Social Welfare, Holden-Day, California (1970): [trad. Española: Elección colectiva y bienestar social, Alianza Universidad (2007), pp. 266.

${ }^{2}$ Karl R. Popper The Open Society and its Enemies, Princeton University Press (1971): pp. 432.

${ }^{3}$ Alejando Gaviria, Del romanticismo al realismo social y otros ensayos, Norma (2005): pp. 211.

${ }^{4}$ Changes in the political experience become stable against the same parties and the political system in general. This phenomenon of voter preferences change with effects on the party system has been studied by Giovanni Sartori, Partidos y sistemas de partidos, Alianza Editorial (2005): pp. 450.

${ }^{5}$ This criterion of social anomie was originally developed by Durhkeim and reworked recently by Peter Waldmann. See, El Estado anómico. Derecho, seguridad pública y vida cotidiana en América Latina, Iberoamericana (2006), pp. 235.
} 
a different social outcome even if the social alternatives available remain the same. Then there can be no neutrality radical. Neutrality is not met; we are not indifferent toward our differences. Assuming you'd rather stay at home than going on holiday, being $\Sigma$ the rest of the welfare state, while you have the opposite preference. The market model can guarantee you go on vacation. Otherwise I'd rather you stay home with his family (being $\Sigma$ the rest of the welfare state), while you want the opposite in my case. These are simply a substitution of alternatives. However, the market will motivates you go on vacation.

All of the above acts in the opposite of Rawlsian "veil of ignorance" preferences are met by comparing the state of their welfare. Neutrality is not a superior force (as opposed to Max Weber)

Someone can take a Protestant conduct: do not believe in the market! Indeed, this is one of the shortcomings of the market mechanism, not being able to develop a comprehensive agenda on our "externalities." And not only in the cases mentioned, but in certain types of collective choice. In the midst of a march that was attacked by African bees, what places offer greater security? Simplified preferences cut the nature of human behavior.

\section{Liberal Values}

In society we have preferences that seem to depend solely on people. $\Sigma$ As everything else in society, Mr. A prefers the single life $(x)$ and $\Sigma$ being anything else, Mr. $A$ is getting married (and), while many others prefer the opposite. It can be argued that the social choice between $\mathrm{x}$ and $\mathrm{y}$ is a purely private matter for $\mathrm{Mr}$. $A$ is the only one involved, while others can only be curious. However, according to Wittgenstein, it is also possible to see a set of rules that would put personal choice reflected in various language games ${ }^{7}$.

In its weakest sense, the condition of rationality states that everyone is absolutely critical in the social choice between at least a couple of alternatives, such as, that $\mathrm{Mr} . A$ is deciding between $x$ and $y$. In general there may be one of these cases. But we must

\footnotetext{
${ }^{6}$ John Rawls, A Theory of Justice, Harvard University Press (1971).

${ }^{7}$ Ludwig Wittgenstein, Diarios / Conferencias, Editorial Gredos (2009): pp. 933.
} 
multiply because (a) there are other examples of such personal decisions, such as, $\mathrm{Mr}$. $A$ meditates a psalm from the Bible of Jerusalem before falling asleep, but others find it more a story of Andersen, and (b) how to sleep there are many ways since $\Sigma$ can be different. Mr. A has had an accident that forces him to sleep on your side facing the wall. So the condition of a liberal minimum (Nozick) shows sufficiently limited in terms of preference options people have.

The formalists can add an even stronger condition of rationality, which we call the condition $L^{*}$, this condition requires that at least two individuals have personal preferences reflected in the social preference on a pair of alternatives each. This condition is extremely fragile and can be called minimalist status of liberalism, as further reducing the number of individuals with such freedom (i.e. reducing it to an individual) will allow an autocracy, and its limits, a dictatorship ${ }^{8}$.

The fact is that these conditions of rationality $L^{*}$ are finally incompatible with the conditions $U$ (unrestricted domain) and $P$ (weak Pareto principle), when placed upon an SDF, as shown by Sen (1970). Open social systems of preference domains and collective decision also expanded the range of opportunities. This impossibility result can be contrasted with Arrow's impossibility theorem.

Although the condition $L^{*}$ (minimum liberalism) is somewhat stronger than the condition of Arrow $D$ (not dictatorship), but is also weaker than what we demand an open society. The terms $U$ and $P$ are shared by Arrow's theorem. The independence of irrelevant alternatives is important in Arrow's theorem, but not in this case addressed. The inability to continue, but it is overwhelmingly in the formal framework of the theorems.

An example may clarify the nature of the problem. Suppose that the social choice is between three alternatives: that Mr. A read a copy of The Adventures of the Good Soldier Švejk (Jaroslav Hasek) that Mr. $B$ can read, or read any of them. We call these alternatives a, b, c, respectively. $\mathrm{Mr} A$, would prefer that no one reads it, after reading and finally that Mr. $B$ does not have a chance. Mr. $B$, he would prefer any of them read it to any of them do, but also prefer that Mr. A reading it, because he wants Mr. A was happy with the ironies of the good soldier. Then Mr. $B$ prefers $a$ to $b$ and $b$ to $c$.

\footnotetext{
${ }^{8}$ A tendency to autocracy rather marked in several countries: Colombia, under the government of President Alvaro Uribe.
} 
Let the liberal argument: given the choice between Mr. $A$ to read and not read anyone their own preference should be reflected in the social preference. So society would prefer not to read anyone to read what Mr. A who considers reading a waste of time. It follows that $\mathrm{c}$ is socially preferable to a. Similarly, there is a liberal argument in favor of $B$ show the preferences of the social choice between that Mr. $B$ will read it and anyone else to do. Thus $b$ is preferred to c. Hence, society should prefer that Mr. $B$ you to do it no one did so and the latter to Mr. $A$ to read it. However, that Mr. $B$ to read as Pareto is worse than read Mr. A, even in terms of weak Pareto criterion, and if the social preference respects degradation, then, is preferable to $b$. In short, each alternative can be considered worse than any other.

The road taken reflects true preferences of social dilemmas. This is not only the limited capacity of choice but also the inability to make an optimal choice. In a dark street a thief assaults his victim: "money or your life." The conditions did not give to speculation. And trading in such situations is impossible. However, in this case is a real dilemma in extreme? Normal life often presents illustrations of lesser risk.

\section{Limitations liberal}

This critique of liberalism $L^{*}$ passed as a critique of solipsism ${ }^{9}$. The assumption that certain things-like states of knowledge-are matters "private and personal" is not sustainable. The music that puts Mr. $A$ does not let you sleep Mr. $B$, then, is a matter also of Mr. $B$. If Mr. $B$ can not pass wonders with music that places $\mathrm{Mr}$. $A$, it means that whatever Mr. $A$ is important for what Mr. $B$. This interdependence is relevant, and has also been strategically assessed the threat of nuclear war ${ }^{10}$.

The context that creates such conditions is related to the concepts developed by Wittgenstein on the meaning of "rule-following"11. In the same way we learn a language, a rule allows us to understand the meaning of certain proscriptions: child pornography, pedophilia, or handling of marijuana. All these aspects make up rules for limiting some people over others. Politics as a device intended to regulate power

\footnotetext{
${ }^{9}$ Wittgenstein: (2009).

${ }^{10}$ Thomas, Schelling: The Strategy of Conflict, Harvard University Press, Cambridge. (1960).

${ }^{11}$ Wittgenstein $(2009,863-867)$.
} 
imbalances $^{12}$. In this respect, liberalism $L^{*}$ shown limited due to the conditions found in open societies. In its formalized version, the condition $L^{*}$ implies a couple of alternatives and only a couple of people. Moreover, with the possibility of a world with such features, the choices would have to be neutral and uniform.

Here's another objection. In an open society manifests respect for personal privacy conditions. However, according to the $\mathrm{L}^{*}$, personal decisions can be enforced. If I am offered to choose between affirming the absolute truth $(x)$ or die $(y)$, under such conditions of freedom is a chimera. This means that the minimum versions of liberalism are difficult, both from a formal point of view and from the perspective of its applications to open societies.

The problem of failure in collective choice much affects personal choice. We can not guarantee individual liberties, although they may be ideal mechanisms of collective choice. This guarantee depends primarily on the development of values and preferences that mutual respect privacy and personal choices. The liberal values of type $L *$ respond to a remote version of classical liberalism, in John Stuart Mill as David Hume, for example, the term liberal is used to refer to a person who is deeply interested in protecting personal freedom from interference of others.

\section{Conclusions}

Conflicts arising from the collective choice can limit the Pareto principle. Moreover, this principle is inapplicable in liberalism least unless we assume that individual preferences are reduced to certain specific patterns. But the Pareto principle $\mathrm{P}$ is adapted to the justifications of liberalism $L^{*}$.

In the analytical expression of liberalism such Nozick, for example, freedom of choice is motivated by the $P$ status of the person $A$, you can take interest in the affairs "personal" $B$, as a justification to consider it also a matter of $A$. Advocates of this position in the public choice also defend possessive individualism.

The importance of formal analysis is that it helps to look at issues not clear in the experience. However, formal systems are often not responding to the complexities of

\footnotetext{
${ }^{12}$ Michel Foucault, Surveiller et punir : Gallimard, (1975).
} 
collective choice. Decisions on political or economic, are always loaded with personal bias. And a majority of situations present us with decisions that we can qualify, then (ex post), as the best in such conditions.

\section{References}

Foucault, Foucault, Surveiller et punir: Gallimard. [trad. Española. Foucault, M. (2005): Vigilar y castigar: nacimiento de la prisión. (A. G. Camino, Trad.) Madrid: Siglo Veintiuno].

Gaviria, Alejandro, Del romanticismo al realismo social y otros ensayos, Norma (2005): pp. 211.

Popper, Karl R. The Open Society and its Enemies: Princeton University Press (1971): pp. 432.

Rawls, John. 1971 A Theory of Justice: Harvard University Press.

Sartori, Giovanni, 2005, Partidos y sistemas de partidos, Alianza Editorial: pp. 450.

Schelling, Thomas, 1960: The Strategy of Conflict, Harvard University Press, Cambridge.

Sen, Amartya K., Collective Choice and Social Welfare, Holden-Day, California (1970): [trad. Española: Elección colectiva y bienestar social, Alianza Universidad (2007), pp. 266.

Waldmann, Peter. El Estado anómico. Derecho, seguridad pública y vida cotidiana en América Latina, Iberoamericana (2006), pp. 235.

Wittgenstein, Ludwig, 2009, Diarios / Conferencias, Editorial Gredos: pp. 933. 